\title{
Contributing factor leading to child drowning: Epidemiologic study over 15 years in Bihor County
}

\author{
Paula Marian', Camelia Buhas ${ }^{1}$, Dumitru Dragnea², Andrada Chira², Cristian Sava ${ }^{1}$ \\ ${ }^{1}$ Faculty of Medicine and Pharmacy, University of Oradea, Romania \\ 2“Dr. Gavril Curteanu“ Municipal Clinical Hospital, Oradea, Romania
}

\begin{abstract}
The authors present in this paper a statistical study that refers to drowning in children. The research was conducted in Bihor County, over a period of 15 years, analyzing an abundant casuistry resulting from professional experience as pediatricians and forensic medicine specialists of reporting authors from the city of Oradea. The most important factors favoring drowning in childhood are reviewed. The following parameters were analyzed: age, gender, place and circumstances of death, the time when the drowning occurred. As a conclusion of the study, it was found that the death occurred more frequently in children older than 5 years of age, who drowned in running waters, most of them during unattended bathing. The authors consider this conclusion an alarm signal and a public health issue that would be useful to be disseminated through all media.
\end{abstract}

Keywords: drowning, child, death, contributing factors

\section{INTRODUCTION}

Drowning is a major public health problem worldwide, ranked third as the leading cause of unintentional injury death $(1,2)$. Approximately 372,000 people die annually from drowning $(3,4)$. It is the leading cause of accidental death in the United States in children aged 1-14 years (5). It is the second most common cause of death, with higher mortality rates among children of immigrants, African Americans and those from disadvantaged families over the age of 4 (6).

Among the relevant factors influencing the patients' outcome after drowning, the following are renowned to have a major impact: age, site and circumstances of drowning, time of day, water temperature, period of submersion, associated injuries (head and neck especially), alcohol and drug abuse $(7,8,9,10)$. Some of these factors are analyzed in this study.

\section{MATERIAL AND METHOD}

We conducted a statistical study regarding the cases of drowned children (both those who died and those who survived) in Bihor County between January 2002 and December 2017. The research was performed at the Municipal Clinical Hospital Dr. Gavril Curteanu Oradea and at the Bihor County Forensic Medicine Service and involved 86 pediatric patients with a diagnosis of drowning, of whom 62 deceased child patients and 24 surviving children. The study took into account children aged 0 to 18 years, victims of drowning, hospitalized or cared for in resuscitation centers. Drowning survivors cared for outside the unit were not included in our study. For all reviewed cases, the following parameters were analyzed: age, gender, place and circumstances of drowning, the time when the drowning occurred.

\section{RESULTS}

TABLE 1. Distribution of cases by years of study

\begin{tabular}{|c|c|c|c|c|}
\hline Year & $\begin{array}{c}\text { Deceased } \\
(n=62)\end{array}$ & $\begin{array}{c}\text { Survivors } \\
(\mathrm{n}=24)\end{array}$ & $\begin{array}{l}\text { Survival } \\
\text { rate (\%) }\end{array}$ & $\begin{array}{c}\text { Statistical } \\
\text { significance* }\end{array}$ \\
\hline 2017 & 4 & 1 & 20 & \multirow[t]{7}{*}{$p=0.1171$} \\
\hline 2016 & 1 & 2 & 66.7 & \\
\hline 2015 & 1 & 0 & 0 & \\
\hline 2014 & 5 & 0 & 0 & \\
\hline 2013 & 2 & 1 & 33.3 & \\
\hline 2012 & 3 & 3 & 50 & \\
\hline 2011 & 4 & 1 & 20 & \\
\hline
\end{tabular}




\begin{tabular}{|c|c|c|c|c|}
\hline Year & $\begin{array}{c}\text { Deceased } \\
(n=62)\end{array}$ & $\begin{array}{l}\text { Survivors } \\
(n=24)\end{array}$ & $\begin{array}{l}\text { Survival } \\
\text { rate (\%) }\end{array}$ & $\begin{array}{c}\text { Statistical } \\
\text { significance* }\end{array}$ \\
\hline 2010 & 5 & 0 & 0 & \multirow[t]{8}{*}{$p=0.1171$} \\
\hline 2009 & 3 & 1 & 25 & \\
\hline 2008 & 3 & 7 & 70 & \\
\hline 2007 & 4 & 2 & 33.3 & \\
\hline 2006 & 3 & 2 & 40 & \\
\hline 2005 & 8 & 2 & 20 & \\
\hline 2004 & 7 & 1 & 12.5 & \\
\hline 2003 & 9 & 1 & 10 & \\
\hline
\end{tabular}

* Chi-square test

There is a difference in the distribution of drowning cases by years of study. There is an improvement in survival (percentages exceeding 50\%) in 2008 and 2016. But this difference does not reach the threshold of statistical significance ( $p$ $=0.171$ ) if we refer to all years of study.

TABLE 2. Distribution of cases by age groups

\begin{tabular}{|c|c|c|c|c|}
\hline Age group & $\begin{array}{c}\text { Deceased } \\
(n=62)\end{array}$ & $\begin{array}{c}\text { Survivors } \\
(\mathrm{n}=24)\end{array}$ & $\begin{array}{l}\text { Survival } \\
\text { rate (\%) }\end{array}$ & $\begin{array}{c}\text { Statistical } \\
\text { significance* }\end{array}$ \\
\hline $0-1$ years & 0 & 3 & 100 & \multirow{3}{*}{$p=0.0106$} \\
\hline $1-4$ years & 11 & 6 & 35.3 & \\
\hline$>5$ years & 51 & 15 & 22.7 & \\
\hline
\end{tabular}

* Chi-square test

The evolution drowning cases was different for the 3 age groups analyzed. Infants had the highest chance of survival, and the most reserved prognosis was for children over 5 years $(p=0.0106)$. The relative risk of drowning increases approximately 4 times in children over 5 years of age compared to infants (0-1-year age group): $\mathrm{RR}=3.7823(95 \%$ CI: 2.13-6.70), $\mathrm{p}<0.0001$. The attributable risk is $77.3 \%$.

This difference does not reach the threshold of statistical significance between infants and children up to 4 years: $\mathrm{RR}=5.1111$ (95\% CI: 0.37 $69.9), p=0.2216$. The attributable risk is $64.7 \%$.

TABLE 3. Distribution of cases by gender

\begin{tabular}{|l|c|c|c|c|}
\hline Gender & $\begin{array}{c}\text { Deceased } \\
(\mathbf{n = 6 2 )}\end{array}$ & $\begin{array}{c}\text { Survivors } \\
(\mathbf{n = 2 4 )}\end{array}$ & $\begin{array}{c}\text { Survival } \\
\text { rate (\%) }\end{array}$ & $\begin{array}{c}\text { Statistical } \\
\text { significance* }\end{array}$ \\
\cline { 1 - 4 } Male & 48 & 16 & 25 & \multirow{2}{*}{$\mathrm{p}=0.4535$} \\
\hline Female & 14 & 8 & 36.4 & \\
\hline
\end{tabular}

* Yates's Chi-squared test

Drowning is more common in boys, and the survival rate is favorable to girls, but this difference is not statistically significant $(\mathrm{p}=0.4535)$. The relative risk of survival for male gender is only 1.1786 (95\% CI: $0.83-1.66)$ compared to females $(\mathrm{p}=0.3521)$. The attributable risk is $11.4 \%$.
TABLE 4. Distribution of cases related to site of drowning

\begin{tabular}{|c|c|c|c|c|}
\hline $\begin{array}{l}\text { Site of } \\
\text { drowning }\end{array}$ & $\begin{array}{c}\text { Deceased } \\
(n=62)\end{array}$ & \begin{tabular}{|c|} 
Survivors \\
$(\mathrm{n}=24)$
\end{tabular} & $\begin{array}{l}\text { Survival } \\
\text { rate (\%) }\end{array}$ & $\begin{array}{c}\text { Statistical } \\
\text { significance* }\end{array}$ \\
\hline River & 25 & \begin{tabular}{|l|}
10 \\
\end{tabular} & 28.6 & \multirow{8}{*}{$p=0.2956$} \\
\hline $\begin{array}{l}\text { Dam, lake, } \\
\text { fishery }\end{array}$ & 7 & 2 & 22.2 & \\
\hline $\begin{array}{l}\text { Canal, } \\
\text { collecting } \\
\text { basin }\end{array}$ & 6 & 0 & 0 & \\
\hline Pools & 5 & 5 & 50 & \\
\hline $\begin{array}{l}\text { Ponds, } \\
\text { swamps, pits }\end{array}$ & 11 & 2 & 15.4 & \\
\hline Shaft, well & 2 & 2 & 50 & \\
\hline $\begin{array}{l}\text { Bathtub, } \\
\text { bucket, barrel }\end{array}$ & 4 & 3 & 42.9 & \\
\hline $\begin{array}{l}\text { Latrine, septic } \\
\text { tank }\end{array}$ & 2 & 0 & 0 & \\
\hline
\end{tabular}

* Chi-square test

The site of drowning does not influence cases evolution after the event; all locations have comparable outcome $(\mathrm{p}=0.8405)$.

TABLE 5. Distribution of cases related to circumstances of drowning

\begin{tabular}{|c|c|c|c|c|c|}
\hline \multicolumn{2}{|c|}{ Circumstances } & $\begin{array}{c}\text { Deceased } \\
(n=62)\end{array}$ & $\begin{array}{c}\text { Survivors } \\
(\mathrm{n}=24)\end{array}$ & $\begin{array}{l}\text { Survival } \\
\text { rate (\%) }\end{array}$ & $\begin{array}{c}\text { Statistical } \\
\text { significance* }\end{array}$ \\
\hline \multicolumn{2}{|c|}{ Suicide } & 1 & 0 & 0 & \multirow{6}{*}{$p=0.1437$} \\
\hline \multirow{5}{*}{ 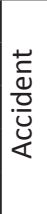 } & Bathing & 21 & 15 & 41.7 & \\
\hline & Unattended & 21 & 5 & 19.2 & \\
\hline & Slide & 10 & 4 & 28.6 & \\
\hline & epilepsy & 2 & 0 & 0 & \\
\hline & alcohol & 7 & 0 & 0 & \\
\hline
\end{tabular}

* chi-square test

Regarding the circumstances of drowning, it does not influence the chances of survival $(p=0.1437)$. However, it is noticed the lack of survivors from accidents associated with epileptic seizures and alcoholism, but the threshold of statistical significance is most likely not reached due to the small number of cases in this situation.

TABLE 6. Distribution of cases by time of the day

\begin{tabular}{|l|c|c|c|c|}
\hline $\begin{array}{l}\text { Time of } \\
\text { the day }\end{array}$ & $\begin{array}{c}\text { Deceased } \\
\text { (n= 62) }\end{array}$ & $\begin{array}{c}\text { Survivors } \\
\text { (n= 24) }\end{array}$ & $\begin{array}{c}\text { Survival } \\
\text { rate (\%) }\end{array}$ & $\begin{array}{c}\text { Statistical } \\
\text { significance* }\end{array}$ \\
\hline $6-14$ & 12 & 5 & 29.4 & \multirow{2}{*}{$\mathrm{p}=0.2407$} \\
\cline { 1 - 4 } $14-22$ & 48 & 16 & 25 & \\
\hline $22-6$ & 2 & 3 & 60 & \\
\hline
\end{tabular}

* Chi-square test

There are differences in survival depending on the time of drowning, in terms of improving the prognosis of nighttime drowning. However, this difference is not statistically significant $(\mathrm{p}=0.2407)$ and should be interpreted with caution given the small number of cases in this category. 


\section{DISCUSSIONS}

In this research we compared the evolution of children, victims of drowning distributed as deceased children and surviving children. Following the similar studies, we found that almost half of the cases of drowning in children were located in the running water, which means that these children remained unattended. Drowning is a serious public health problem that causes 372,000 deaths a year worldwide. Of these, over $90 \%$ are predominantly in low- and middle-income countries. There are many effective strategies to prevent drowning, which can be implemented not only at home but also in society, for example: enrolling children in swimming lessons, installing barriers to limit access to water (e.g. swimming pools) and placing safe places for children at home etc. (11).

Following the distribution of cases by years, there was a relatively slight decrease in time of drowning cases, so that between 2003 and 2008 the annual average is higher compared to 20092017 where the annual cases it's more decreased. This difference does not reach the threshold of statistical significance, but there is a significant decrease over time in cases of drowning (12).

The study observed a $100 \%$ predominance of cases of drowning in the tub among infants, an aspect corroborated with data from the "World Report on the Prevention of Injuries in Children" according to which infants most often drown in the bathtub, children 1-4 year olds drown in swimming pools and other children over 5 years old drown in streams, lakes or swimming pools $(13,14,15)$. The main cause of death among accidents in the US is drowning, in children aged 1 to 14 this is also the second leading cause of death, and the mortality rate is higher in children of immigrants, African Americans and those from families disadvantaged people over the age of $4(16,17)$.

Depending on the time of drowning, out of the 86 cases studied, 64 cases of children drowned in the range of 14-22 were identified, observing indisputably the increased incidence of drowning cases during the day (18).

The present study allowed me to evaluate the report on the number of drowning cases and

\section{REFERENCES}

1. Berger LR, Wallace LJ, Bill NM. Injuries and injury prevention among indigenous children and young people. Pediatr Clin North Am. 2009;56(6):1519-37.

2. Kyriacou DN, Arcinue EL, Peek C, Kraus JF. Effect of immediate resuscitation on children with submersion injury. Pediatrics. 1994; 94(2 Pt 1):137-42. drowning survivors and on the other hand the minimum and maximum knowledge of the parents regarding the provision of first aid in such situations, and the purpose of retrospective clinical research was not only the analysis and interpretation, but also the comparison of epidemiological, clinical, paraclinical data and the evolution of cases of children surviving drowning with current data from the literature. Half of the cases collected and illustrated in the present study were victims of drowning with children drowned in bathing, and $30.23 \%$ were secondary to lack of supervision from parents or adults. Usually the survival of the drowned child depends largely on the speed and efficiency of first aid and the intervention with which action is taken on the spot because they can have important longterm repercussions, especially in improving the prognosis of the child drowning (19).

\section{CONCLUSIONS}

Following the survey, we found that most children died after they drowned in the river.

Death was more common while bathing and in cases of unsupervised children regardless of the place and time of the drowning.

The age most commonly involved was over five years-age group.

No survivors were recorded in the case of accidents associated with seizures and alcohol consumption.

Regarding the survival rate of the drowned children, it depends to a large extent on the speed and efficiency of first aid intervention taken on the spot, because they can have important long-term repercussions, especially in improving the prognosis of the child drowning.

The conclusions of this research should be a warning for public health services in terms of prevention and intervention methods for rescuing drowning children.

We consider it useful to make the population aware about the possibility of the child drowning, by publicizing the cases, the rescue measures that are required and the prevention ones.

Conflict of interest: none declared Financial support: none declared
3. Brenner RA, Taneja GS, Haynie DL, Trumble AC, Qian C, Klinger RM et al. Association between swimming lessons and drowning in childhood: a case-control study. Arch Pediatr Adolesc Med. 2009; 163(3):203-10.

4. Christophe C, Fonteyne C, Ziereisen F, Christiaens F, Deltenre P, De Maertelaer $V$ et al. Value of MR imaging of the brain in children with hypoxic coma. AJNR Am J Neuroradiol. 2002;23(4):716-23. 
5. Kawati R, Covaciu L, Rubertsson S. Hypothermia after drowning in paediatric patients. Resuscitation. 2009;80(11):1325-6.

6. Fisher B, Peterson B, Hicks G. Use of brainstem auditory-evoked response testing to assess neurologic outcome following near drowning in children. Crit Care Med. 1992;20(5):578-85.

7. Baciu G. Expertiza medico-legală a cadavrului și persoanei (Ghid practic). Ministerul Sănătății al Republicii Moldova, USMF "Nicolae Testemițanu", Chișinău, 2008;25-44.

8. Beliş V. Tratat de medicină legală. Ed. Medicală, Bucureşti, 1995:66-68;85-126.

9. Mihalache G, Buhaş C. Compendiu de medicină legală pentru medici generalişti şi stomatologi. Ed. Universității din Oradea, 2007:23-36

10. Sava CN, Ritli L, Balmos AB, luhas AR, Marian P, Motorca MA, Lele LA, Straciuc O, Zaha DC, Jurca MC, Niula L, Negrut N. Unusual extramedullary relapses in a case of common B-cell acute lymphoblastic leukemia. Case report and review of literature. Rom J Morphol Embryol. 2019;60(1):249-254.

11. Van Beeck EF, Branche CM, Szpilman D, Modell JH, Bierens JJ. A new definition of drowning: towards documentation and prevention of a global public health problem. Bull World Health Organ. 2005; 83(11):853-6.
12. Brenner RA, Trumble AC, Smith GS, Kessler EP, Overpeck MD. Where children drown, United States, 1995. Pediatrics. 2001; 108(1):85-9.

13. Orlowski JP. Drowning, near-drowning, and ice-water submersions. Pediatric Clin North Am. 1987;34(1):75-92.

14. U.S. Consumer Product Safety Commission. Safety Barrier Guidelines for Home Pools. Cited Mar 2007.

15. Thompson DC, Rivara FP. Pool fencing for preventing drowning in children. Cochrane Database Syst Rev. 2000;CD001047.

16. Suominen P, Baillie C, Korpela R, Rautanen S, Ranta S, Olkkola KT. Impact of age, submersion time and water temperature on outcome in near-drowning. Resuscitation. 2002;52(3):247-54.

17. Van Beelen ME, van Beeck EF, den Hertog P, Beirens TM, Raat $H$. Correlates of unsupervised bathing of infants: a crosssectional study. Int J Environ Res Public Health. 2013;10(3):856-66.

18. Jan MM. Pediatric near-drowning and drowning. Saudi Med J. 2013; 34(2):119-22.

19. Rahman A, Shafinaz S, Linnan M, Rahman F. Community perception of childhood drowning and its prevention measures in rural Bangladesh: a qualitative study. Aust J Rural Health. 2008; 16(3):176-80. 